\title{
Research and Manufacturing of New Type Lightweight and High-strength Foam Concret
}

\author{
Zi-bo Tang \\ College of Mining and Safety Engineering, Shandong \\ University of Science and Technology, Qingdao \\ Shandong 266590, China \\ Baodian coal mine Yanzhou coal co., LTD., Zoucheng, \\ Shandong, 273512, China \\ 961343546@qq.com \\ Xian-jun Tan \\ Yankuang Group co., LTD., Postdoctoral research \\ station, Zoucheng, 273512; China \\ China State Key Laboratory of Geomechanics and \\ Geotechnical Engineering, Institute of Rock and Soil \\ Mechanics, Chinese Academy of Sciences, Wuhan, \\ Hubei 430071, China \\ xjtan@whrsm.ac.cn
}

\begin{abstract}
In order to solve the problems like large mass of concrete block, high labor intensity of workers and low construction efficiency in the ordinary masonry-filling combined construction technology which are used in continuously mining and quick gob-side entry retaining technologies, this article carried out indoor proportion experimental study on lightweight and high-strength foam concrete (LHFC). The study results show that, the preparation of foam concrete materials with density level of $1200 \mathrm{~kg} / \mathrm{m3}$ and uniaxial compressive strength of $10-15 \mathrm{MPa}$ by chemical foaming method and optimizing proportion through adding three materials which are silica, slag and flyash to match with the structure system of "cement + fine sand" can completely be realized.
\end{abstract}

Keywords-gob-side entry retaining; foam concrete; concrete block

\section{INTRODUCTION}

Concrete is artificial stone block made of binding materials, coarse aggregate, fine aggregate, water and additives which are mixed in accordance with a certain proportion and coagulated and hardened after a certain time [1-3]. Featured by extensive sources of raw materials, simple and convenient preparation technique, easy

\author{
Peng-qiang ZHENG \\ Department of Resources and Civil Engineering, \\ Shandong University of Science and Technology, Tai' \\ an, Shandong 271019, China \\ pqzheng_1231@163.com \\ De-shun KONG \\ Baodian coal mine Yanzhou coal co., LTD., Zoucheng, \\ Shandong, 273512, China \\ 1021397542@qq.com
}

formation processing, low cost and good mechanical properties, it is widely applied in civil buildings, bridges, tunnels, water conservancy and hydropower, underground space and other various building engineering and is the most widely used artificially prepared building material with the largest consumption in today's world [4-6]. Continuously mining and quick gob-side entry retaining technology of Dongtan Coal Mine No. 2 Coal Bed has used masonry-filling combined construction technology and has gained good effects. However, in the course of use, problems like large mass of concrete block, high labor intensity of workers and low construction efficiency are found to exist, which cause the development of concrete materials with high strength and light weight for gob-side entry retaining. Foam concrete is the light weight concrete with large number of sealed pores which is made by the way of physical and chemical foaming and upon curing. Since there are a large number of small sealed pores, foam concrete is lighter than the general concrete. However, because of the characteristics of foam concrete itself, the foam concrete products currently sold in the market universally have the drawbacks of low strength, large contraction, and being easily cracked and so on [7-11]. 


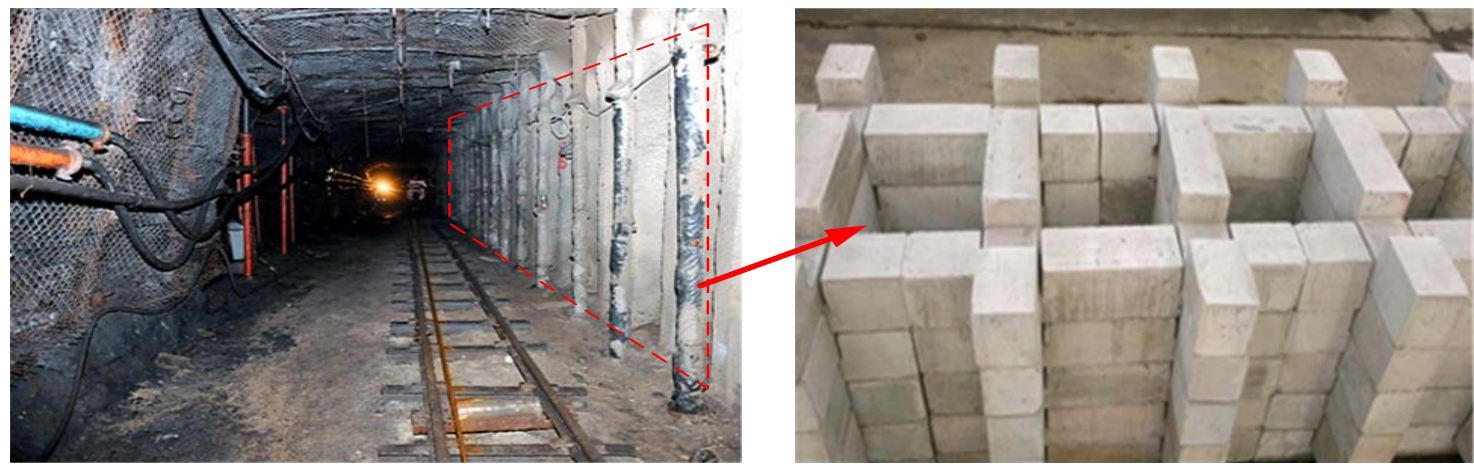

Figure 1. gob-side entry retaining by concrete block at Dongtan Coal Mine No. 2 Coal

\section{EXPERIMENTAL DETAILS}

\section{A. Testing Raw Materials}

(1) Cement: The cement is PII silicate cement produced by Huaxin Cement Co., Ltd. and sold in the market.

(2) Fly ash is Grade I flyash sold in the market, and its properties comply with provisions of Flyash Used in Cement and Concrete.

(3) Fine aggregate is standard sand grain sold in the market (50 meshes).

(4) Foaming agent is industrial hydrogen peroxide sold in the market $(27.5 \%)$.

(5) Fiber is modified polypropylene fasciculation, $19 \mathrm{~mm}$ Y monofilament or modified polypropylene fasciculation and monofilament produced by Jiangsu Sheyang Yonggu Engineering Fiber Equipment Co., Ltd. and sold in the market.
(6) Water reducing agent is polycarboxylate high-property water reducing agent.

(7) Silica fume, flyash and slag are of ordinary specification sold in the market.

\section{B. Testing Scheme}

In accordance with previous research results, the reference formula of foam concrete with density level of $1200 \mathrm{~kg} / \mathrm{m} 3$ and uniaxial compressive strength of $10-15 \mathrm{MPa}$ is: $80 \%$ PII silicate cement, $20 \%$ standard sand (50 meshes), $0.2 \%$ polycarboxylate superplasticizer (including $40 \%$ solid content), $0.2 \%$ hardener, $0.6 \%$ activator, $4.5 \%$ foaming agent, $0.5 \%$ polypropylene fiber, and the water-material proportion is 0.3 (refer to Table 1 Testing Scheme 1\#). In order to ensure that uniaxial compressive strength of block reaches to above $15 \mathrm{MPa}$, this test uses silica fume, slag and flyash to match with the structure system of "cement + fine sand" (refer to Table 1 for the specific testing scheme).

TABLE I MiXing Proportion OF High-Property AND Lightweight FoAm CONCRETE TeST

\begin{tabular}{|c|c|c|c|c|c|c|c|}
\hline $\begin{array}{c}\text { Sample } \\
\text { No. }\end{array}$ & Cement/g & $\begin{array}{c}\text { Other } \\
\text { Admixtures/g }\end{array}$ & $\begin{array}{l}\text { Sand } \\
/ \mathrm{g}\end{array}$ & $\begin{array}{l}\text { Foaming } \\
\text { Agent/g }\end{array}$ & $\begin{array}{c}\text { Polypropylene } \\
\text { Fiber/g }\end{array}$ & $\begin{array}{c}\text { Water } \\
\text { Reducing } \\
\text { Agent/g }\end{array}$ & $\begin{array}{c}\text { Water-Material } \\
\text { Proportion }\end{array}$ \\
\hline $1 \#$ & 960 & 0 & 240 & 45 & 5 & 1.6 & 0.3 \\
\hline $2 \#$ & 840 & $\begin{array}{l}120 \text { Silica } \\
\text { Fume }\end{array}$ & 240 & 45 & 5 & 1.6 & 0.3 \\
\hline $3 \#$ & 840 & 120 Slag & 240 & 45 & 5 & 1.6 & 0.3 \\
\hline $4 \#$ & 840 & 120 Flyash & 240 & 45 & 5 & 1.6 & 0.3 \\
\hline $5 \#$ & 840 & $\begin{array}{l}60(\text { Slag })+ \\
60(\text { Flyash }) \\
60 \text { (Silica }\end{array}$ & 240 & 45 & 5 & 1.6 & 0.3 \\
\hline $6 \#$ & 840 & $\begin{array}{l}\text { Fume })+60 \\
\text { (Flyash) } \\
\quad 60 \text { (Silica }\end{array}$ & 240 & 45 & 5 & 1.6 & 0.3 \\
\hline $7 \#$ & 840 & $\begin{array}{c}\text { Fume })+60 \\
(\text { Slag })\end{array}$ & 240 & 45 & 5 & 1.6 & 0.3 \\
\hline
\end{tabular}


Specific to the chemical foaming system put forward in this project, standard curing is made upon formation of samples. The section of foaming direction of samples produced by the test is shown as Fig .3.

\section{Testing RESULTS AND ANALYSIS}

\section{A. Lightweight and LHFC Stress-Strain Testing}

\section{Phenomenon and Result Analysis}

Stress-strain curve test was carried out in this project on samples with different mixing proportions, and the test failure form is shown as Fig .4. Stress-strain curve in different stages gained from testing scheme 1\# is shown as Fig .5.

Just like ordinary concrete, the failure process of prismatic concrete samples prepared in this project can also be divided into the following stages:

Stage 1: Stable Crack Producing Stage. At this stage, concrete stress is relative small $(\sigma<0.3 \mathrm{fc} \sim 0.5 \mathrm{fc})$, and the cracks produced are mainly the bonding cracks. When the loading remains unchanged, new cracks will not be produced and the concrete is basically in flexible working stage.

Stage 2: Stable Crack Developing Stage. If the loading at this stage remains unchanged, the development of cracks will stop immediately. At this stage, the Poisson ratio of concrete is usually within the scope of 0.15 0.22.

Stage 3: Instable Crack Developing Stage. When the stress of samples reaches to $0.7 \mathrm{fc} \sim 0.9 \mathrm{fc}$, the internal micro-cracks of concrete have relatively big development, but there are still no visible big penetrating cracks on the surface of samples. The Poisson ratio of lightweight and high-strength foam concrete (LHFC) rapidly increases, and the volume of samples transforms from compression to expansion. Before long, the concrete will reach to the ultimate bearing capacity fc.

Stage 4: After the concrete has reached to the ultimate bearing capacity fc, the loading it bears reduces gradually while the strain of samples constantly increases. The bearing capacity of the whole concrete rapidly declines and causes destruction of samples, and the angle between the failure surface and loading vertical line is $53^{\circ} \sim 76^{\circ}$, showing the vulnerability of materials.

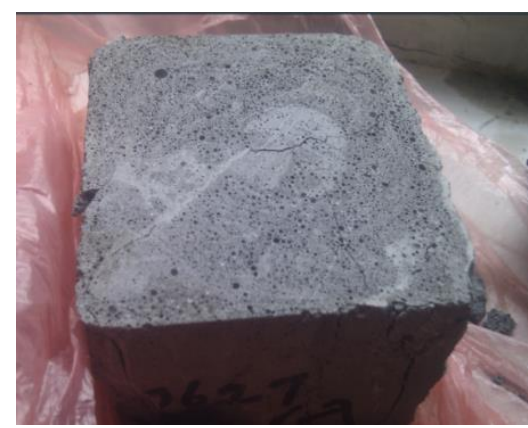

(a) Crack Producing Stage

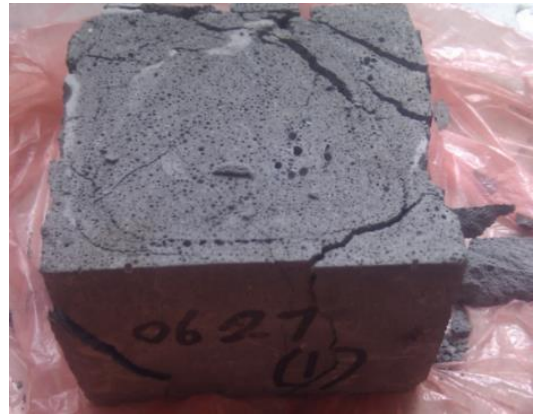

(b) Crack Developing Stage

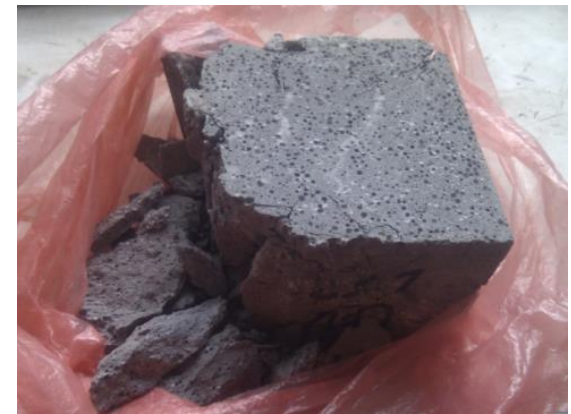

(c) Crack Penetrating Stage

Figure 4. Sample Failure and Development Form

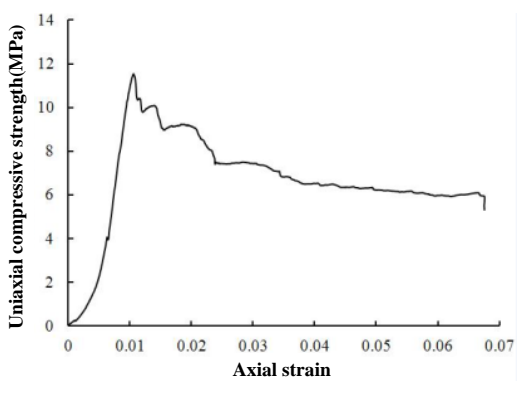

(a) 3 Days

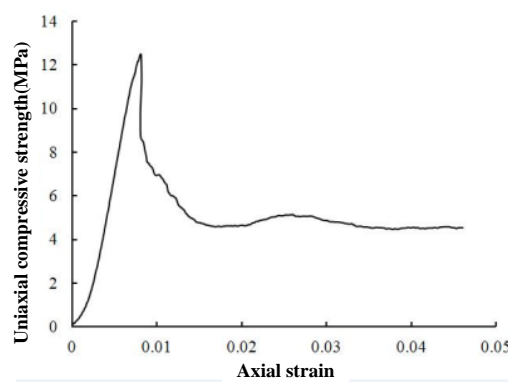

(b) 7 Days

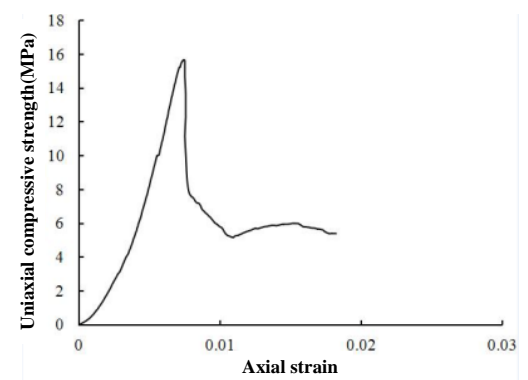

(c) 28 Days

Figure 5. Testing Scheme 7\# Stress-Strain Curve in Different Stages

Limited by the length of this article, this report will not show stress-strain curve in different stages of other testing schemes anymore and only demonstrate uniaxial compressive strength in different stages as shown in Table 2. 


\begin{tabular}{cccc}
\hline \multirow{2}{*}{ Sample No. } & \multicolumn{3}{c}{ Uniaxial Compressive Strength/[MPa] } \\
\cline { 2 - 4 } $1 \#$ & 3 Days & 7 Days & 28 Days \\
\hline $2 \#$ & 8.52 & 10.51 & 12.27 \\
$3 \#$ & 9.89 & 12.83 & 14.72 \\
$4 \#$ & 9.64 & 13.32 & 14.38 \\
$5 \#$ & 7.20 & 10.68 & 13.26 \\
$6 \#$ & 11.04 & 13.96 & 14.75 \\
$7 \#$ & 10.80 & 12.40 & 15.02 \\
\hline
\end{tabular}

\section{CONCLUSIONS}

In order to solve the problems like large mass of concrete block, high labor intensity of workers and low construction efficiency in the ordinary masonry-filling combined construction technology which are used in continuously mining and quick gob-side entry retaining technologies, this article carried out indoor proportion experimental study on lightweight and high-strength foam concrete (LHFC). The study results show that, the preparation of foam concrete materials with density level of $1200 \mathrm{~kg} / \mathrm{m} 3$ and uniaxial compressive strength of $10-15 \mathrm{MPa}$ by chemical foaming method and optimizing proportion through adding three materials which are silica, slag and flyash to match with the structure system of "cement + fine sand" can completely be realized

\section{ACKNOWLEDGEMENTS}

This work was supported by the National Program on Key Basic Research Project (973 Program) (Grant Nos. 2013CB036006 and 2015CB057906), the National Natural Science Foundation of China (Grant Nos. 51208499, 41102193 and 51109207), the Postdoctoral Science Foundation of China (2014M550365), and the National Science Fund for Distinguished Young Scholars of China (Grant No. 51225902).

\section{REFERENCES}

[1] Tan XJ, Chen WZ, Tian HM, Cao JJ. Degradation characteristics of foamed concrete with lightweight aggregate and polypropylene fibre under freeze-thaw cycles. Magazine of concrete research 2013; 65(12): 720-730.

[2] Aguilar RA, Diaz OB, Garcia JIE. Lightweight concretes of activated met kaolin-fly ash binders, with blast furnace slag aggregates. Constr Build Mater 2010; 24(7): 1166 - 75.

[3] ACI Committee 207, Mass concrete, ACI Manual of Concrete Practice, Part 1, American Concrete Institute, Detroit, 1994.

[4] Wang Q, LI X, Zhao G, SHAO P, YAO J. Experiment on mechanical properties of steel fiber reinforced concrete and application in deep underground engineering. Journal of China University of Mining and Technology 2008;18:64-81.

[5] French C, Mokhtarzadeh A, Ahlborn T, Roberto L. High-strength concrete applications to prestressed bridge girders. Constr Build Mater 1998;12:105-113.

[6] Karastathis VK, Karmis PN, Drakatos G, Stavrakakis G. Geophysical methods contributing to the testing of concrete dams. Application at the Marathon Dam. J Appl Geophys 2002;50:247-260.

[7] Ramamurthy K, Nambiar E, Ranjani G. A classification of studies on properties of foamed concrete. Cement Concrete Comp 2009;31:388-396

[8] Laukaitis A, Zurauskas R, Keriene J. The effect of foam polystyrene granules on cement composite properties. Cem Concr Comp 2005;27:41-7.

[9] Park SB, Yoon ES, Lee BI. Effects of processing and materials variations on mechanical properties of lightweight composites. Cem Concr Res 1998;29(2):193-200.

[10] X.J., Tan; W.Z., Y.G., Hao. Experimental Study of Ultralight $(<300 \mathrm{~kg} / \mathrm{m} 3)$ Foamed Concrete. Advances in Materials Science and Engineering, 2014.

[11] Kearsley EP, Wainwright PJ. The effect of high fly ash content on the compressive strength of foamed concrete. Cement Concrete Res 2001;31:105-112. 